\title{
Hemiscrotal agenesis: a novel phenotype of a rare malformation
}

\author{
Mohamed Mansy ${ }^{1}\left(\mathbb{D}\right.$, Mostafa Kotb $^{2^{*}}$ (D), Yasmine Abdelmeguid ${ }^{3}$ (D), Shaymaa Raafat ${ }^{3}$ (D) and Marwa Abdelaziz ${ }^{4}$ (D)
}

\begin{abstract}
Background: Hemiscrotal agenesis (HSA) is an exceedingly rare congenital anomaly in scrotal development. It is characterized by unilateral absence of scrotal skin with intact midline raphe. In the English literature, only seven patients were diagnosed with HSA. Herein, we report a 14-month-old boy with HSA, unilateral cryptorchidism and a perineal skin tag. Additionally, the patient had a monodactylous limb, unilateral cerebellar hypoplasia, and a cardiac septal defect.

Case presentation: A 14-month-old boy presented with right HSA and ectopic scrotal skin in the right perineal region. Extra-genital examination showed right monodactylous lower limb, without dysmorphic facial features or any other skeletal anomalies. His karyotype was $46, \mathrm{XY}$, while his hormonal profile showed prepubertal LH and FSH. Skeletal survey showed right monodactylous lower limb (with only a big toe which had 2 phalanges) and normal spine alignment. A previous echocardiography was done and showed a small muscular ventricular septal defect (VSD) that closed on follow-up. Magnetic resonance imaging of the brain showed posterior fossa malformation. The patient had his right testis fixed in the right scrotum. The pathological examination of the perineal lesion showed fibro-epithelial polyp (skin tag), with no testicular tissue or atypia.

Conclusion: We believe that this is the first case to be reported with hemiscrotal agenesis and ipsilateral cryptorchidism, associated with a perineal skin tag, unilateral monodactylous lower limb on the same side, unilateral cerebellar hypoplasia, and VSD. Interestingly, further genetic analysis is required to reach a final diagnosis. However, regrettably, advanced molecular diagnostic studies for this patient is not available in our country.
\end{abstract}

Keywords: Case report; Hemiscrotal agenesis; Monodactylous limb

\section{Background}

Hemiscrotal agenesis (HSA) is a very rare congenital anomaly in scrotal development. It is characterized by unilateral absence of scrotal skin with intact midline raphe [1]. In the English literature, only seven patients were diagnosed with HSA [1-7]. Occasionally, this anomaly can be associated with extra-genital anomalies as a part of a syndrome, which supports the existence of a genetic background in these patients [2].

\footnotetext{
* Correspondence: mostafa.rashad@alexmed.edu.eg

${ }^{2}$ Department of Pediatric Surgery, Alexandria Faculty of Medicine, 21615 Alexandria, Egypt

Full list of author information is available at the end of the article
}

This anomaly is proposed to be due to primary failure of labioscrotal folds development or secondary to localized 5-alpha-reductase type 2 deficiency or androgen insensitivity $[1,2]$. Herein, we report a 14-month-old boy with HSA, unilateral cryptorchidism and a perineal skin tag. Furthermore, the patient had a monodactylous limb, unilateral cerebellar hypoplasia, and a cardiac septal defect.

\section{Case presentation}

A 14-month-old boy was referred to our hospital for atypical genitalia. He is the only child, born to nonconsanguineous parents by cesarean section after an uneventful pregnancy. Examination of external genitalia revealed absence of scrotal rugae on the right side, ipsilateral

C C The Author(s). 2020 Open Access This article is licensed under a Creative Commons Attribution 4.0 International License, which permits use, sharing, adaptation, distribution and reproduction in any medium or format, as long as you give appropriate credit to the original author(s) and the source, provide a link to the Creative Commons licence, and indicate if changes were made. The images or other third party material in this article are included in the article's Creative Commons licence, unless indicated otherwise in a credit line to the material. If material is not included in the article's Creative Commons licence and your intended use is not permitted by statutory regulation or exceeds the permitted use, you will need to obtain permission directly from the copyright holder. To view a copy of this licence, visit http://creativecommons.org/licenses/by/4.0/. The Creative Commons Public Domain Dedication waiver (http://creativecommons.org/publicdomain/zero/1.0/) applies to the data made available in this article, unless otherwise stated in a credit line to the data. 


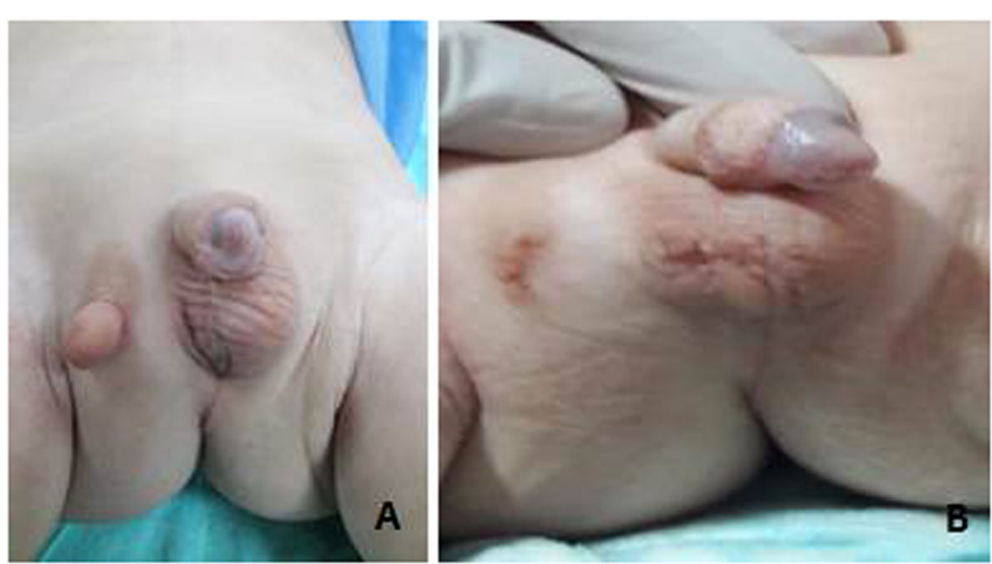

Fig. 1 a. A preoperative photo showing absence of scrotal rugae on the right side, ipsilateral cryptorchidism and abnormal external tissue on the right side of the perineum. b. The same patient 6 months after the ochiopexy

cryptorchidism and abnormal external tissue on the right side of the perineum (Fig. 1). The right testis was palpable in the inguinal region, the left testis was in the scrotum with intact midline raphe, and his penile length was $4.8 \mathrm{~cm}$ (normal for age). Ultrasonography showed that both testes were normal in size and echotexture. Extra-genital examination showed right monodactylous lower limb, normal tone and deep tendon reflexes. He had no dysmorphic facial features or any other skeletal anomalies. (Fig. 2a).

The karyotype of the boy was $46, \mathrm{XY}$, while his hormonal profile showed normal prepubertal LH and FSH (0.1, $0.4 \mathrm{mIU} / \mathrm{ml}$ respectively). After B-hCG stimulation, serum total testosterone increased from $0.03 \mathrm{ng} / \mathrm{ml}$ to $3.51 \mathrm{ng} / \mathrm{ml}$ (normal basal serum total testosterone: up to 0.3, normal serum total testosterone after $\beta$-hCG

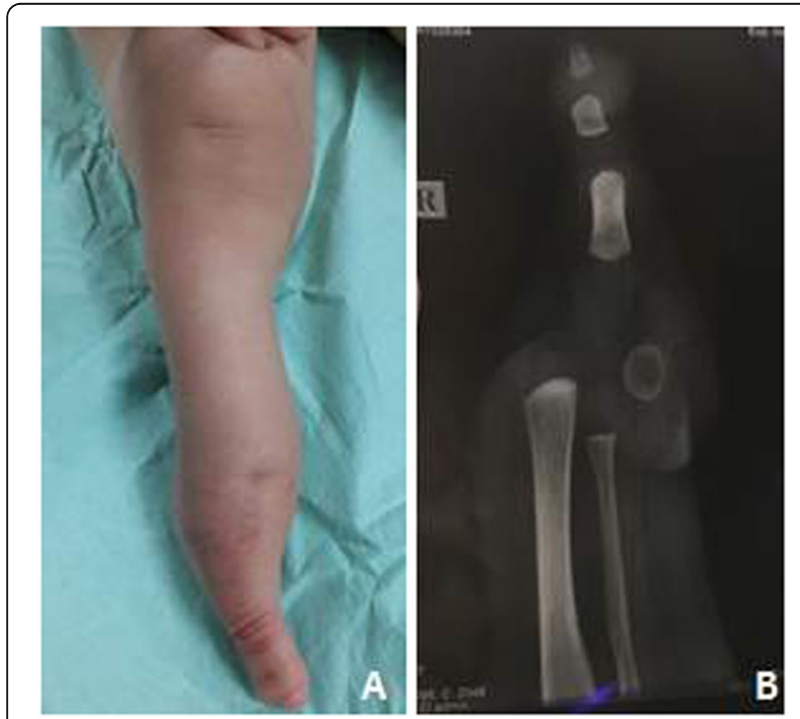

Fig. 2 a. Limb examination showed right monodactylous lower limb. b. Skeletal survey showed right monodactylous lower limb with only a big toe with 2 phalanges stimulation: more than 2-fold rise) and testosterone/dihydrotestosterone ratio was $8.54 \mathrm{ng} / \mathrm{ml}$ (normal: up to 30). Moreover, he had normal sertoli cell function which was assessed by measuring inhibin-B and anti-Müllerian hormone which were $158 \mathrm{pg} / \mathrm{ml}$ (normal: 91-163) and $23 \mathrm{ng} / \mathrm{ml}$ (normal: above 15), respectively.

In addition, work-up for associated extra-genital anomalies was done. Skeletal survey showed right monodactylous lower limb (with only a big toe which had 2 phalanges) (Fig. 2b) and normal spine alignment. This limb malformation resulted in motor developmental delay for which he started to stand supported with the help of orthopedic shoes, physical and occupational therapy. There was neither a family history of similar condition nor seizures, abnormal movements or ataxia. Associated intra-abdominal anomalies including renal system abnormalities were excluded by abdominal and pelvic ultrasonography. A previous echocardiography showed a small muscular ventricular septal defect (VSD) that closed on follow-up.

Magnetic resonance imaging of the brain showed posterior fossa malformation in the form of dysplastic left cerebellar hemisphere with hypoplasia of its antero-superior compartment, total aplasia of its postero-inferior compartment and a small cleft traversing the inferior aspect of the right cerebellar hemisphere (Fig. 3). Despite that no seizures were reported, right focal epileptiform activity was detected by electroencephalogram. Audiological examination revealed bilateral normal function, and his ophthalmological examination was normal.

Intra-operatively, the patient had his right testis fixed in the right scrotum. Two biopsies were taken; one of them from the scrotal skin and the other from the perineal lesion. The pathological examination of the perineal lesion showed fibro-epithelial polyp (skin tag), with no testicular tissue or atypia (Fig. 4). 

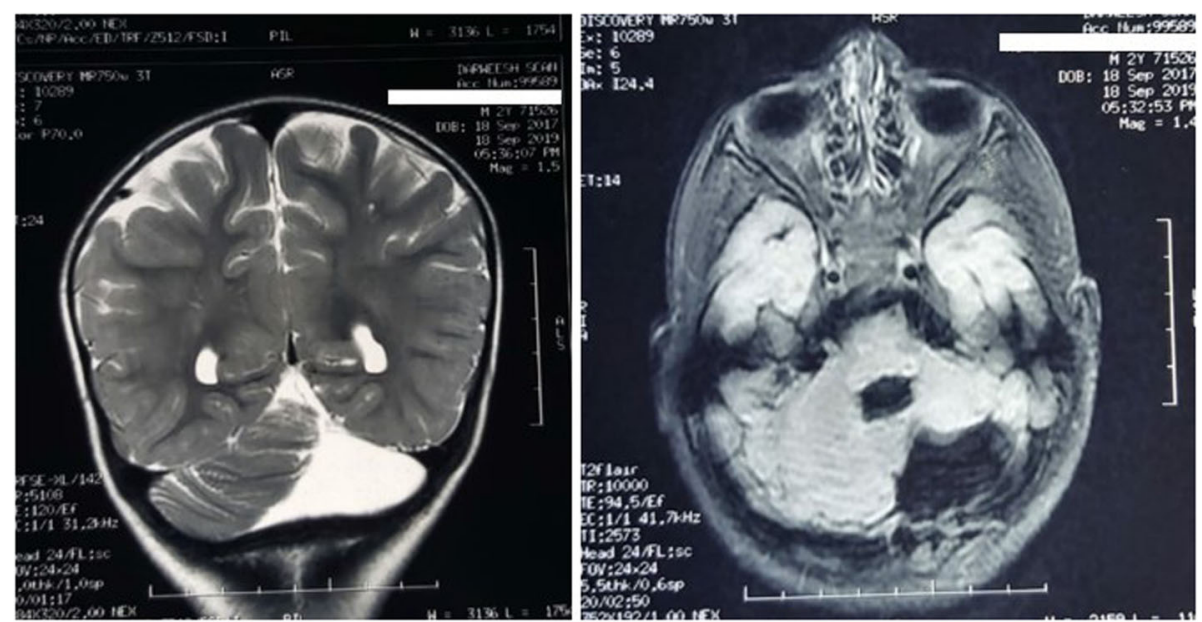

Fig. 3 Magnetic resonance imaging of the brain revealed hypoplasia of the antero-superior compartment and total aplasia of the postero-inferior compartment of the left cerebellar hemisphere

\section{Discussion}

Scrotal agenesis either bilateral or unilateral is considered to be an extremely rare developmental anomaly of the scrotum [8]. During fetal life, scrotal development starts by formation of labioscrotal folds on both sides of the urogenital folds in the 7th embryonic week. Testosterone reaches its peak during the 10th gestational week and is converted by the enzyme 5-alpha reductase into more potent dihydrotestosterone (DHT), which induces virilization of the external genitalia [9]. At the 16th gestational week, fusion of the labioscrotal folds occurs to form the scrotum $[1,3]$.

Despite that the embryological development of the external genitalia is well known, the exact embryological etiology of scrotal agenesis is still unknown. Maldevelopment of labioscrotal folds is considered to be the cause of scrotal agenesis by either mechanical or endocrine disorders [8]. It is also proposed that localized partial androgen insensitivity and 5a-reductase type 2 deficiency may be the cause. However, enough DHT is produced to prevent labia formation without stimulation of scrotal development, as evidenced by the presence of the midline raphe $[1-3,9]$.

Although the number of HSA cases reported in literature is scarse, the clinical phenotype varies. Three of the reported cases were associated with ipsilateral cryptorchidism $[2,4,5]$ and the remaining 3 had complete testicular descent $[1,3,6]$. Moreover, scrotal agenesis may present as an isolated anomaly or may be associated with a variety of other congenital defects such as face anomalies, growth retardation, cardiac anomalies, anterior ectopic anus, digit anomalies $[1,4,10]$. Of the reported cases with HSA, 1 patient had PHACE syndrome, 1 patient had Van der Woude syndrome, and 1 had cutis marmorata telangiectatica congenita, and hydronephrosis due to vesicoureteral reflux $[3,6,7]$. Only 1 patient

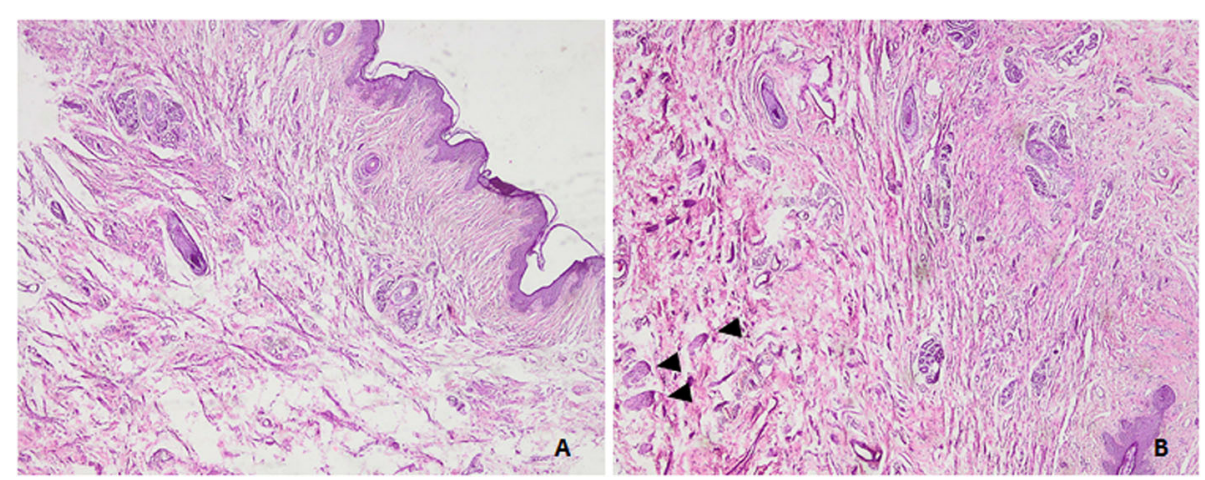

Fig. 4 a. Scrotal skin showing corrugated skin surface composed of a thin layer of keratinized stratified squamous epithelium, overlying scattered slender smooth muscle bundles representing the superficial layer of dartos muscle (arrows). Scattered hair follicles and sweat glands are seen. No sebaceous glands are found. [H\&E X40]. b. The deep reticular dermis shows few scattered thick smooth muscle bundles representing the deep layer of dartos muscle (arrowheads). Note the complete absence of subcutaneous fat. [H\&E X40] 
had an island of scrotal tissue in the pubic tubercle region, in addition to HSA [4].

As regards limb anomalies associated with atypical genitalia, few patients were shown to have mutation in human gene HOXA13 and HOXD13. HOX genes encode a family of transcription factors that play a major role in the development of the central nervous system, axial skeleton, gastrointestinal and urogenital tracts, external genitalia, and limbs during embryonic development. Mutations in these genes cause a wide range of malformations. The most common amongst these malformations are hand-foot-genital syndrome caused by HOXA13 gene mutation, and synpolydactyly caused by HOXD13 mutation. The severity of the phenotypic manifestation of these diseases is variable, and depends on the exact mutation type [11-13]. Interestingly, the presence of HAS along with unilateral cerebellar hypoplasia and unilateral monadactylus limb possibly suggest a vascular disruptive origin and according to Stephens, a possible mechanical pressure effect on the developing fetus could be the implicating factor [14].

To our best knowledge, this is the first case to be reported with hemiscrotal agenesis and ipsilateral cryptorchidism associated with a perineal skin tag, unilateral monodactylous lower limb on the same side, unilateral cerebellar hypoplasia, and VSD. Interestingly, further genetic analysis is required to reach a final diagnosis. Unfortunately, advanced molecular diagnostic studies for this patient is not available in our country.

\section{Abbreviations}

DHT: Dihydrotestosterone; HSA: Hemiscrotal agenesis; VSD: Ventricular septal defect; ß-hCG: ß-subunit of Human chorionic gonadotrophin

\section{Acknowledgements}

We thank Prof. Sameh Shehata, Professor of Pediatric Surgery, Alexandria Faculty of Medicine for his continuous and endless support, and tips in the process of publication.

\section{Authors' contributions}

YA and MA conceptualized the report and drafted, reviewed and revised the manuscript. SR, MM and MK provided specific details related to the case, as well as reviewed and revised the manuscript. All the authors have read and approved the final manuscript as submitted and agree to be accountable for all aspects of the work.

\section{Funding}

There was no funding source for this report.

\section{Availability of data and materials}

Data sharing is not applicable to this article as no datasets were generated or analysed during the current study.

\section{Ethics approval and consent to participate}

No ethics approval is required in the authors' institution for case reports.

Informed consent was obtained from the parents for this report.

\section{Consent for publication}

A written informed consent was obtained from the parents for the publication of this report.

\section{Competing interests}

The authors declare that they have no competing interests.

\section{Author details}

${ }^{1}$ Pediatric Surgery, Port Said Faculty of Medicine, Port Said, Egypt.

${ }^{2}$ Department of Pediatric Surgery, Alexandria Faculty of Medicine, 21615

Alexandria, Egypt. ${ }^{3}$ Pediatric Endocrinology, Alexandria Faculty of Medicine,

Alexandria, Egypt. ${ }^{4}$ Pathology, Alexandria Faculty of Medicine, Alexandria,

Egypt.

Received: 21 May 2020 Accepted: 9 November 2020

Published online: 28 November 2020

\section{References}

1. Yılmaz E, Afşarlar ÇE, Karaman I, Özgüner IF, Karaman A, Hızlı F. Congenital hemiscrotal agenesis: report of a rare entity. J Pediatr Urol. 2013;9:76-7.

2. Nishio $H$, Mizuno K, Moritoki $Y$, Kamisawa $H$, Naiki T, Kurokawa S, et al. Hemiscrotal agenesis: pathogenesis and management strategies. Int J Urol. 2016:23:523-6.

3. Flum AS, Chaviano AH, Kaplan WE. Hemiscrotal agenesis: new variation in a rare anomaly. Urology. 2012;79:210-1.

4. Psarris A, Dimopoulou A, lakomidis E, Zavras N, Vaos G. Hemiscrotal Agenesis: A Rare Congenital Anomaly. J Clin Diagn Res. 2017;11:PD19-20.

5. FangY, Lin J, Wang WW, Qiu J, Xie Y, Sang LP, et al. Unilateral congenital scrotal agenesis with ipsilateral cryptorchidism: A case report. World J Clin Cases. 2019;7:3807-11.

6. Eliezer DD, Goel H, Turner VM, Deshpande A. Hemiscrotal agenesis with complete testicular descent in Van der Woude syndrome: a new phenotypic feature. BMJ Case Rep. 2019;12:e229938.

7. Corona-Rivera JR, Acosta-León J, León-Hernández MÁ, Martínez-Macías FJ, Bobadilla-Morales L, Corona-Rivera A. Co-occurrence of hemiscrotal agenesis with cutis marmorata telangiectatica congenita and hydronephrosis affecting the same side of the body. Am J Med Genet A. 2014;164A:199203.

8. Janoff DM, Skoog SJ. Congenital scrotal agenesis: description of a rare anomaly and management strategies. J Urol. 2005;173:589-91.

9. Mohan PP, Woodward MN, Chandran H, Parashar K. Topical testosterone in scrotal agenesis. Pediatr Surg Int. 2006;22:565-6.

10. Wright JE. Congenital absence of the scrotum: Case report and description of an original technique of construction of a scrotum. J Pediatr Surg. 1993; 28:264-66.

11. Goodman FR. Limb malformations and the human HOX genes. Am J Med Genet. 2002;112:256-65.

12. Snajdr P, Grim M. Liska F.HOX genes and the limb development in the clinical praxis and in the experiment. Cas Lek Cesk. 2010;149:4-9.

13. Campo MD, Jones MC, Veraksa AN, Curry CJ, Jones KL, Mascarello JT, et al. Monodactylous limbs and abnormal genitalia are associated with hemizygosity for the human 2q31 region that includes the HOXD cluster. Am J Hum Genet. 1999;65:104-10.

14. Stephens FD. Embryology of the cloaca and embryogenesis of anorectal malformations. Birth Defects Orig Artic Ser. 1988;24:177-209.

\section{Publisher's Note}

Springer Nature remains neutral with regard to jurisdictional claims in published maps and institutional affiliations.

Ready to submit your research? Choose BMC and benefit from:

- fast, convenient online submission

- thorough peer review by experienced researchers in your field

- rapid publication on acceptance

- support for research data, including large and complex data types

- gold Open Access which fosters wider collaboration and increased citations

- maximum visibility for your research: over $100 \mathrm{M}$ website views per year

At BMC, research is always in progress.

Learn more biomedcentral.com/submissions 